\title{
Mechanical Behavior of Layered YSZ Thermal Barrier Coatings using Indentation Test
}

\author{
Dong Heon Lee and Kee Sung Lee ${ }^{\dagger}$
}

School of Mechanical Systems Engineering, Kookmin University, Seoul 136-702, Korea

(Received August 12, 2011; Revised September 10, 2011; Accepted September 14, 2011)

\section{압입시험법에 의한 YSZ 층상 열차폐 코팅재의 기계적 거동 \\ 이동헌 $\cdot$ 이기성 ${ }^{\dagger}$ \\ 국민대학교 기계시스템공학부 기계설계전공}

(2011년 8월 12일 접수 ; 2011년 9월 10일 수정 ; 2011년 9월 14일 승인)

\begin{abstract}
In this study, we investigated the mechanical behaviors of layered thermal barrier coatings by indentations. Various single and double-layered thermal barrier coatings were deposited by air plasma spray process using different type of commercialized YSZ (Yttria stabilized zirconia) starting powders. Indentation stress-strain curve, load-displacement curve and hardness of the single and the double-layered thermal barrier coatings were obtained experimentally and analyzed. The indentation damages at the same loads were compared, and thus, the results depend on the structure of each coating. The result indicates improvement in damage resistances from tailoring of layered structures in the component of gas turbine system is expected.
\end{abstract}

Key words : Thermal barrier coatings, Gas turbine, Hertzian contact, Indentation

\section{1. 서 론}

가스터빈 시스템은 기계적 에너지를 이용하여 전기에 너지를 발생시키는 시스템으로서, 공기를 압축시켜 연료 와 함께 연소시켜 그 힘으로 터빈을 돌리게 되며, 이 때 전기를 발생시켜 공급한다. 이 시스템은 작동온도가 높을 수록 에너지 효율이 우수하므로 최근 국내에서는 $1100^{\circ} \mathrm{C}$ 급에서 $1350^{\circ} \mathrm{C}$ 급으로 작동온도가 상승되는 추세에 있으 며 미국 등 선진국에서는 $1500^{\circ} \mathrm{C}$ 급 이상도 연구되고 있 다. 따라서 높은 온도에 견디기 위해서는 내구성이 우수 한 세라믹스가 열차폐 코팅재로서 사용된다. ${ }^{1-3)}$

세라믹스 열차폐 코팅재로서 최근 열전도도가 낮은 대 체재에 대한 연구가 활발하지만, ${ }^{1,2,4-7)}$ 우수한 기계적 특 성과 bondcoat와의 열팽창, 수축시의 적합성이 가장 바람 직한 YSZ(부분안정화 지르코니아)가 여전히 가스터빈 부 품에 적용되고 있다. 그러나 YSZ과 bondcoat와의 열팽창 계수 불일치로 인하여, 고온에서 장기간 가스터빈을 구동 한 후, YSZ의 코팅층이 박리되는 현상이 코팅의 수명을 단축시키는 가장 큰 문제점으로 지적되고 있고, ${ }^{8,9)}$ 가스 터빈 업계에서는 주기적으로 코팅층의 손상여부를 관찰

\footnotetext{
${ }^{\dagger}$ Corresponding author : Kee Sung Lee

E-mail : keeslee@kookmin.ac.kr

Tel : +82-2-910-4834 Fax : +82-2-910-4839
}

하고 보수하고 있다. 특히 우리나라와 같이 기동정지가 많은 시스템의 여건 상, 코팅층의 손상은 반드시 해결되 어져야 할 과제이다.

세라믹스 열차폐 코팅층의 손상은 열팽창, 수축의 반복 을 통한 계면박리가 가장 많이 일어나지만, 가스터빈 운 전 도중 미립자의 충격 및 접촉에 의한 마모, 연소가스에 의한 침식 및 진동에 의한 피로응력, 높은 온도에 의한 크립에 의해서도 일어난다. ${ }^{10-12)}$ 열팽창, 수축의 반복에 의 한 계면박리도 온도변화에 의한 기계적 응력이 부과되어 일어나므로 기계적 거동에 대한 연구는 중요한 주제 중 의 하나이다. 따라서 최근에는 세라믹스 열차폐 코팅층의 내구성 향상을 위한 연구가 국내외에서 활발히 이루어지 고 있으며 내구성 향상을 위한 여러 방법과 기술이 제시 되고 있다. ${ }^{12-16)}$

내구성 향상을 위한 방법의 하나로서, 열팽창계수 차이 를 줄이고 특성을 최적화시키는 방법으로서 다양한 방법 이 제시되고 있으며, 그 중 하나의 기술로서 다층상 코팅 기술이 제시되고 있다. 단층 열차폐 코팅층이 아닌 다층 코팅으로 인하여 제조 시의 기계적 응력이 완화될 수 있 으며, 사용 도중의 열환경이나 기계적 하중 하에서의 손 상내구성도 증가될 수 있는 장점이 기대된다. ${ }^{17,18)}$

본 연구에서는 Sulzer metco사에서 생산하고 있는 topcoat 용 2종류와 bondcoat용 2종류의 상용분말들을 사용하여, 
대기플라즈마 용사(Air Plasma Spray, APS) 장비를 이용 하여 다층상으로 열차폐 코팅재를 제조한 후, indentation 기법으로 특성을 평가하였다. ${ }^{2,10,19,20)}$ 서로 다르게 조합하 여 제조한 각각의 층상 열차폐 코팅재의 표면을 연마가 공한 후 구형의 압자로 압흔응력(indentation stress)을 가 하여 압흔응력-변형율 곡선(indentaiton stress-strain) 및 하 중-변위(load-displacement) 곡선을, Vickers 압흔법으로 경 도데이터를 얻어낸 후, 각 층상 열차폐 코팅재의 기계적 거동을 분석하고 고찰하였다.

\section{2. 실험 방법}

\subsection{APS 공정을 이용한 열차폐 코팅재의 제조}

열차폐 코팅을 하기 위한 기판소재로서 니켈계 초내열 합금(Nimonic 263, ThyssenKrupp VDM, Germany)을 직 경 1 인치, 두께 약 $5 \mathrm{~mm}$ 로 가공하여 사용하였다. Bondcoat 분말과 topcoat를 위한 분말은 Sulzer metco사에서 구매한 분말로서 AMDRY 461NS (Ni-Cr-Al-Co- $\mathrm{Y}_{2} \mathrm{O}_{3}$, Sulzer Metco, Switzerland)와 AMDRY 9625 (Ni-Cr-Al- $\mathrm{Y}_{2} \mathrm{O}_{3}$, Sulzer Metco, Switzerland)의 두 종류의 bondcoat 분말과, $204 \mathrm{NS}, 204 \mathrm{C}$ NS $\left(\mathrm{Y}_{2} \mathrm{O}_{3}-\mathrm{ZrO}_{2}\right.$, Sulzer Metco, Switzerland) 두 종류의 topcoat 분말을 사용하였다.

APS 장비(Triplex-200, Sulzer Metco, Switzerland)를 이 용하여 각 분말을 플라즈마에 의해 고온, 고압으로 기판 에 코팅하였다. 코팅 전에 접합강도를 향상시키기 위하여 알루미나 입자로 샌드블라스트(sandblast) 처리를 해주었 다. 이후 Nimonic 263의 코인시편에 bondcoat 분말을 코 팅하였다. Bondcoat의 코팅조건으로서 $\mathrm{Ar} / \mathrm{He}=30: 20$ 의 부피비가 되도록 제어한 후 분당 총 3.5 리터의 유동속도 로 분말을 공급하였다. Spray gun과 기판간의 거리를 $180 \mathrm{~mm}$ 로 고정시킨 후, power $450 \mathrm{~A} / 90 \mathrm{~V}$ 로 분당 $90 \mathrm{~g}$ 의 분말을 공급하여 기판에 bondcoat 분말을 코팅하였다. Topcoat의 코팅조건으로서는 $\mathrm{Ar} / \mathrm{He}$ 의 혼합비를 $45: 5$ 로 고정시킨 후 분당 3 리터의 유동속도로 분말을 공급하였 다. Spray gun과 기판간의 거리를 $150 \mathrm{~mm}$ 로 고정시킨 후, power $540 \mathrm{~A} / 99 \mathrm{~V}$ 로 분당 $100 \mathrm{~g}$ 의 분말을 공급하여 bondcoat 위에 topcoat 분말을 코팅하였다.

코팅층의 두께는 각 단층의 두께가 bondcoat의 경우 $100 \mu \mathrm{m}$, topcoat 의 경우 $200 \mu \mathrm{m}$ 가 되도록 제어하였다. 이층상으로 코팅할 경우에는 bondcoat의 경우 각각의 두 께가 $100 \mu \mathrm{m}$ 가 되도록 하여 총 bondcoat의 두께는 $200 \mu \mathrm{m}$ 가 되도록 제어하였으며, topcoat의 경우 각 층의 두께가 $200 \mu \mathrm{m}$ 가 되도록 제조하여, 총 두께가 $400 \mu \mathrm{m}$ 가 되도록 제어하였다. 각각의 두께편차는 모든 경우 $10 \%$ 를 넘지 않도록 제어하였다.

서로 다른 bondcoat 분말 및 topcoat 분말을 사용하여 제조한 층상형 열차폐 코팅재의 종류를 Table 1 에 정리하 였다. 한편 현재 발전사에서 사용하고 있는 가스터빈 내 연소기 버너부품(OEM 버너)의 열차폐 코팅재를 성일 SIM 주식회사를 통해 구입하여 분석하였다.

구매한 bondcoat 분말과 topcoat 분말을 주사전자현미경 (SEM)을 이용하여 확대, 관찰하여 입자크기 및 형상, 분 포를 확인하였다. OEM 버너 및 제조된 열차폐 코팅재를 가공, 경면연마한 후 표면처리 해 주었다. 각 열차폐 코 팅재의 상, 하면을 다이아몬드 $10 \mu \mathrm{m}$ 의 연마기로 평면 연 마하였으며, 이후 표면을 $1 \mu \mathrm{m}$ 까지 경면 연마하였다. 경 면 연마된 표면을 광학현미경으로 50 배 및 100 배 확대 관 찰하였으며, 이미지 분석기(image analyzer)를 이용하여 전 체 면적에 대한 기공의 면적 비를 계산하여 기공률을 측 정하였다.

\section{2. 압흔응력에 의한 기계적 거동 평가}

압흔응력에 의한 기계적 거동을 평가하기 위해 반경 $r=2.32 \mathrm{~mm}$ 을 갖는 구형의 초경 볼(tungsten carbide ball, $\mathrm{WC})$ 을 준비하였다. 초경 볼을 지그에 부착한 후 만능 하 중 시험기(Instron 5567, U.S.A.)에 장착하였다.

$0.2 \mathrm{~mm} / \mathrm{min}$ 의 일정한 속도로 층상형 열차폐 코팅재의 표면에 $P=500 \mathrm{~N}$ 부터 $P=1500 \mathrm{~N}$ 까지 압흔응력을 가하 였으며, 최대 하중에 도달한 이후에는 역시 동일한 속도 인 $0.2 \mathrm{~mm} / \mathrm{min}$ 으로 하중을 제거하였다.

Table 1. Layered Thermal Barrier Coatings Tested in This Study

\begin{tabular}{cccc}
\hline & Name & Topcoat powder & Bondcoat powder \\
\hline \multirow{4}{*}{ Single Layer } & 204NS/9625 & 204NS & AMDRY 9625 \\
& $204 \mathrm{NS} / 461 \mathrm{NS}$ & $204 \mathrm{NS}$ & AMDRY 461NS \\
& $204 \mathrm{C}-\mathrm{NS} / 9625$ & $204 \mathrm{C}-\mathrm{NS}$ & AMDRY 9625 \\
& 204C-NS/461NS & 204C-NS & AMDRY 461NS \\
\hline \multirow{3}{*}{ Double Layer } & NS/C-NS/9625/461NS & 204NS on 204C-NS & AMDRY 9625 on AMDRY 461NS \\
& NS/C-NS/461NS/9625 & 204NS on 204C-NS & AMDR 461NS on AMDRY 9625 \\
& C-NS/NS/9625/461NS & 204C-NS on 204NS & AMDRY 461NS on AMDRY 9625 \\
\hline
\end{tabular}


일정한 최대 하중까지 압흔응력을 가한 후, 표면에 형 성된 손상(damage)을 광학현미경(optical microscope, Hanra precision Co., Korea)을 이용하여 50배, 100배의 배율로 관찰한 후 이미지를 $\mathrm{PC}$ 에 저장하였다. 이 때 빛의 간섭 을 이용하여 표면의 굴곡 차를 보다 선명히 관찰할 수 있 는 Nomarski interference contrast법으로 국부적인 소성영 역(local plastic zone)의 형성여부를 관찰하였다. ${ }^{19)}$ 각 하 중에 의해 형성된 손상영역의 직경 $(2 a)$ 을 측정하여 각 하 중에서의 압흔 응력(indentation stress, $\mathrm{GPa}$ )과 압흔 변형률 (indentation strain)을 다음 식 (1)과 (2)에 의해 구한 후, 각 열차폐코팅 구조체의 압흔 응력-변형률 곡선을 구하였다.

Indentation stress, $p_{\mathrm{o}}=P / \pi a^{2}$

Indentation strain, $a / r$

또한 초경볼로 코팅재의 표면을 압흔할 때 미리 장착 한 변위센서(displacement sensor)를 이용하여 하중-변위 곡 선을 얻었으며, 이 곡선으로부터 압흔응력에 의한 기계적 거동을 분석하였다.

한편 Vickers indentation 시험기를 이용하여 각 층상형
열차폐 코팅재의 경면연마된 표면에 $P=10 \mathrm{~N}$ 으로 압흔하 여 압흔 자국의 대각선 길이 $2 a$ 를 측정하여 다음 (3)식에 의하여 경도 값 $(H$, hardness $)$ 을 계산하였다.

$$
H=P / 2 a^{2}
$$

\section{3. 결과 및 고찰}

열차폐 코팅재에 사용된 초기분말들을 주사전자 현미 경으로 관찰한 사진을 Fig. 1에 나타내었다. 204C-NS는 분말의 입도분포가 좁고, $204 \mathrm{NS}$ 는 입도분포가 204C-NS 보다 넓은 것을 알 수 있다. 즉 $204 \mathrm{NS}$ 분말은 상대적으 로 입도가 크고 작은 분말들로 이루어져 있으며, 반면 204 C-NS 분말은 입자크기가 비교적 균일한 분말들로 이루어 져 있음을 확인하였다. 또 AMDRY $461 \mathrm{NS}$ 는 입자형상 이 각진 형상이며, AMDRY 9625는 구형인 것으로 파악 되었다.

경면 연마된 각 열차폐 코팅재의 표면을 반경 $r=2.32 \mathrm{~mm}$ 의 초경 구형압자(J\&L Industrial Supply Co., MI, U.S.A.) 를 이용하여 $P=1500 \mathrm{~N}$ 의 힘으로 각각 압흔응력을 발생시 킨 후, 표면에 형성된 손상(damage)을 광학현미경으로 관

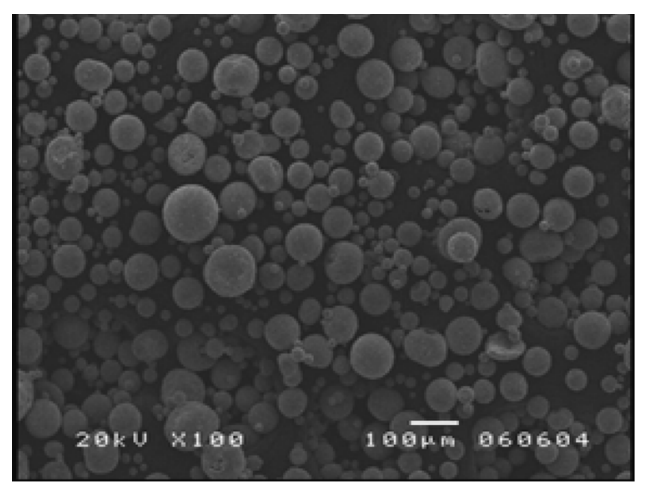

(a)

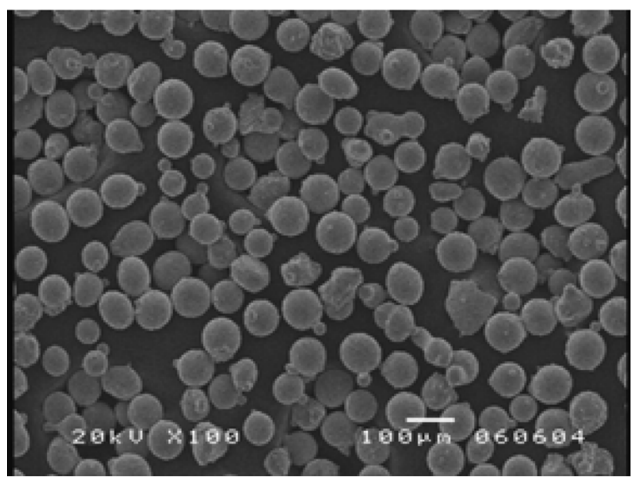

(c)

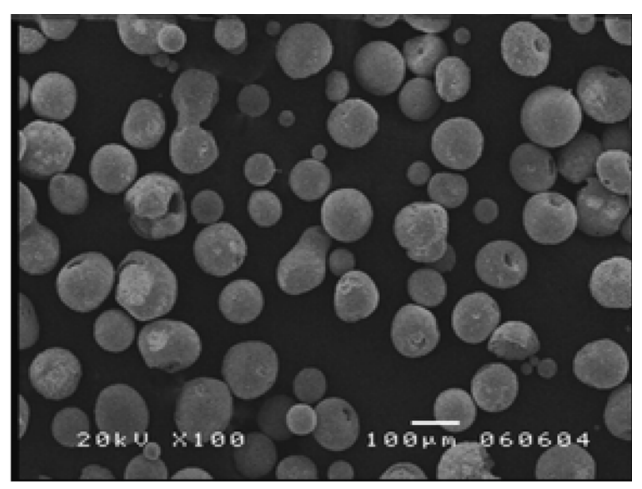

(b)

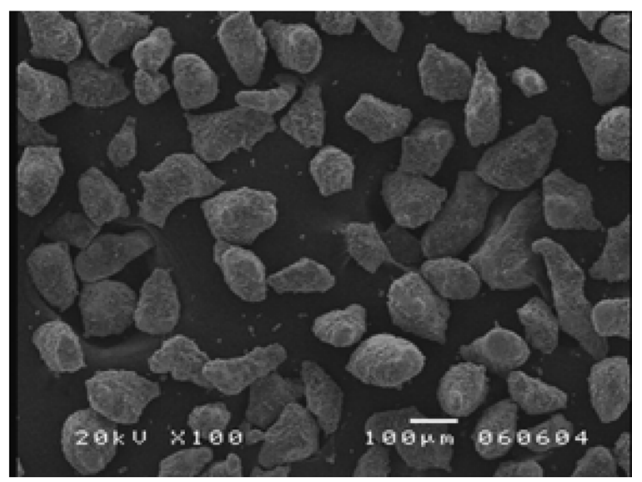

(d)

Fig. 1. SEM micrographs of commercialized starting powders for topcoat and boncoat of thermal barrier coatings; (a) 204NS, (b) 204C-NS, (c) AMDRY 9625, and (d) AMDRY 461NS. 


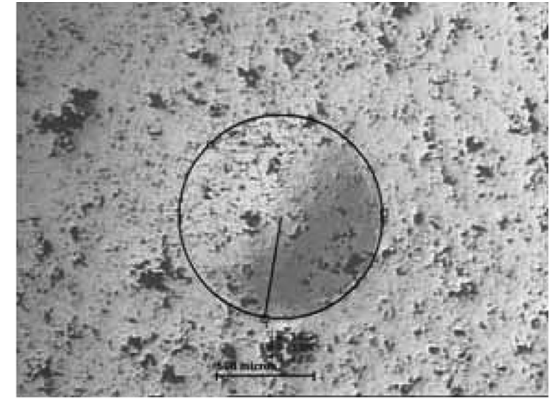

(a)

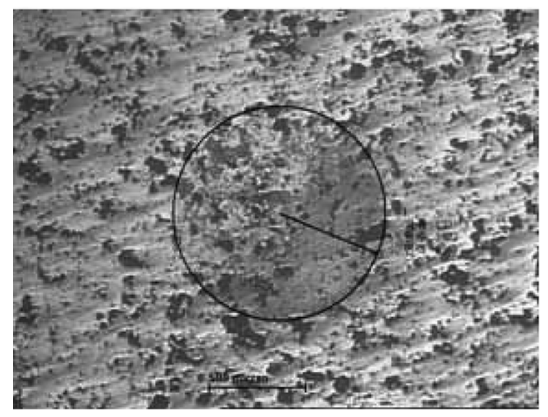

(c)

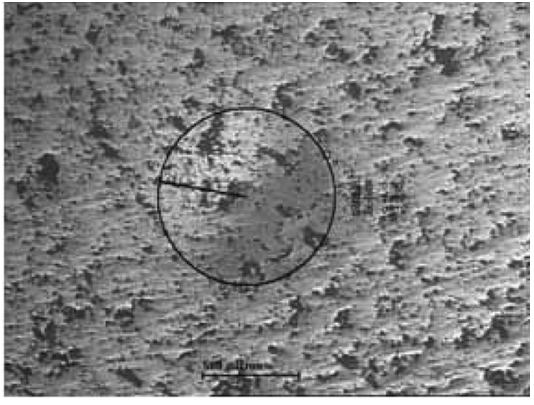

(b)

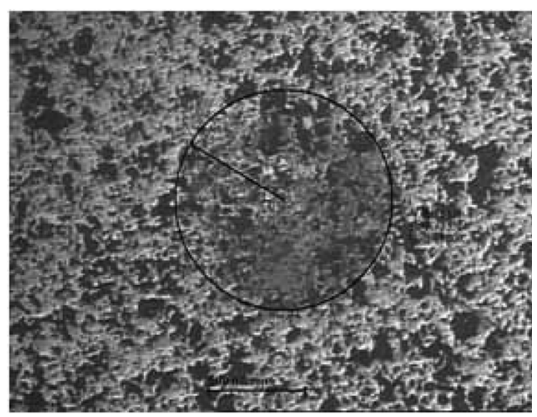

(d)

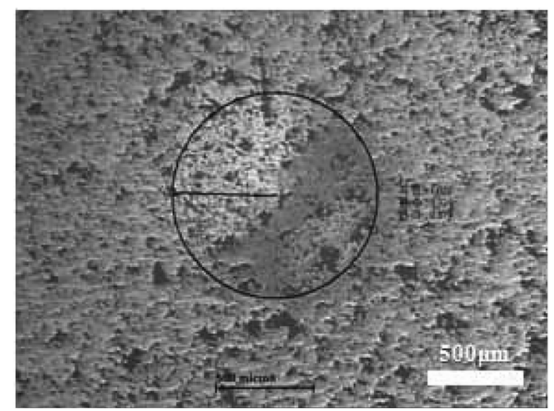

(e)

Fig. 2. Optical micrographs of surface damage by indentation of $\mathrm{WC}$ sphere $r=2.32 \mathrm{~mm}$ at the same load $P=1500 \mathrm{~N}$ for various thermal barrier coatings; (a) 204NS/461NS, (b) 204NS/9625, (c) 204C-NS/9625, (d) C-NS/NS/461NS/9625, and (e) NS/CNS/9625/461NS.

찰한 사진을 Fig. 2의 (a)부터 (e)에 각각 나타내었다. 모 든 사진은 Nomarski illumiantion 하에서 같은 배율로 관 찰한 것이며, 사진에서와 같이 YSZ 열차폐 코팅재에 형 성된 손상은 균열보다는 소성영역(quasi-plastic damage)이 형성되었다. 그림에서 (a)와 (b)는 bondcoat을 461NS, 9625 로 다르게 코팅한 후 topcoat을 204NS로 균일하게 코팅 한 경우로서, bondcoat의 영향을 살펴본 것이다. 사진에서 와 같이 $461 \mathrm{NS}$ 를 bondcoat으로 사용한 경우가 상대적으 로 손상(damage)의 크기가 큰 것을 알 수 있다. Fig. 2의 (b)와 (c)는 bondcoat을 AMDRY 9625로 균일하게 코팅한 후, topcoat을 204NS, 204C-NS로 서로 다른 분말을 이용 하여 코팅한 것으로서, topcoat의 영향을 알 수 있다. 사
진에서와 같이 $204 \mathrm{NS}$ 를 topcoat으로 코팅한 경우가 상대 적으로 손상(damage)의 크기가 작았는데, 이는 표면 미세 구조에서 관찰할 수 있듯이 상대적으로 적은 기공율 $(10 \%$, $204 \mathrm{C}-\mathrm{NS}$ 의 경우는 $19 \%$ 로 측정되었음)에 의한 것이다. 각 사진에서 검은 상으로 보이는 것들이 코팅 후에 형성된 기공들이다. Fig. 2의 (a) (c)와 다르게 (d)와(e)는 서로 손 상의 크기가 유사하였다. 이는 서로 다른 4 종류의 분말을 이용하여 bondcoat 및 topcoat을 각각 이층상으로 제조한 열차폐 코팅재를 동일한 반경의 초경 구, 동일한 하중으 로 평가한 결과로서, 다층상의 경우 손상의 크기가 상호 유사한 것을 알 수 있다.

각 열차폐 코팅재의 표면을 일정한 하중과 일정한 반경 
의 초경구로 압흔한 후 손상영역의 크기 $a$ 를 측정한 후, (1)식과 (2)식에 의해 압흔응력, 변형율을 계산하여 압흔 응력-변형률 선도를 도시하였고, 일정한 하중까지 압흔할 때 하중-변위 곡선을 얻었다. Fig. 3은 OEM 버너에 대해 측정한 압흔 응력-변형률 선도와 하중-변위 곡선의 결과 이다. 그래프에서와 같이 응력이 증가하면 Fig. 3(a)과 같 이 위로 볼록한 형태로 변형률이 점차 증가한다. X. Z. $\mathrm{Hu}$ 등은 층상형 소재에 대한 압흔 응력과 변형율 간의 관계에 대해 다음과 같은 역학식을 제시하였다. ${ }^{21)}$

$$
p_{\mathrm{o}}=\left(4 E_{\mathrm{c}}{ }^{*} / 3 \pi\right)\left(E_{\mathrm{s}}{ }^{*} / E_{\mathrm{c}}\right)^{L}(a / r)^{n}
$$

윗 식에서 $p_{0}$ 와 $a / r$ 은 (1)식과 (2)식에서 주어진 압흔응 력, 변형율 이며, $E$ 는 탄성계수를 나타내며, $E^{*}$ 는 시험편 과 압흔하는 구형압자(indenter)의 탄성계수로부터 보정된 값이다. ${ }^{19)} c$ 와 $\mathrm{s}$ 는 코팅층(coating)과 기판층(substrate)의 약 자이며, $L, n$ 은 재료에 의존하는 상수이다.

한편, 하중에 따른 변위곡선을 도시하면 Fig. 3(b)와 같 이 아래로 볼록한 형태로 곡선이 얻어진다. 이러한 곡선

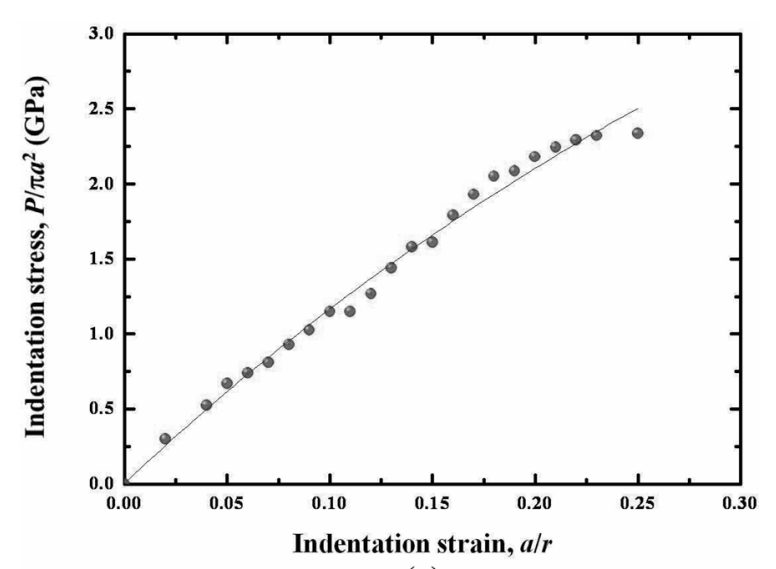

(a)

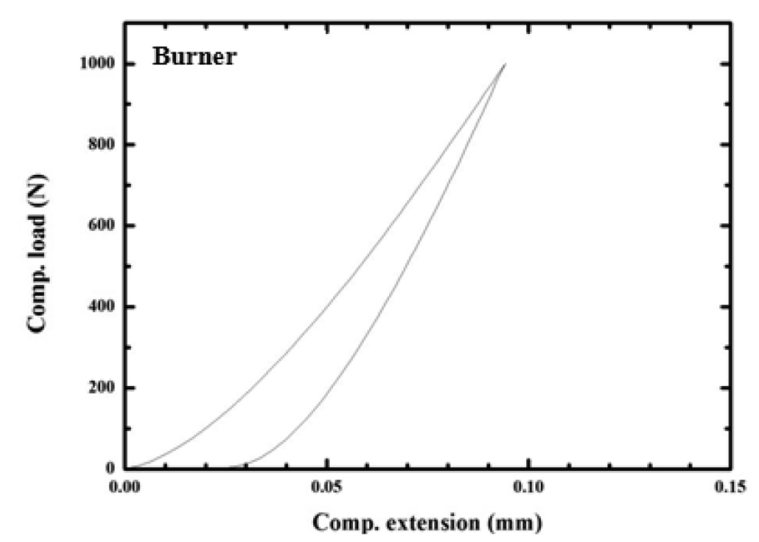

(b)

Fig. 3. The graphs showing the mechanical behaviors of OEM burner component, (a) Hertzian indentation stress-strain curve and (b) indentation load-displacement curve.
의 형태는 기존의 연구결과와 잘 일치하는 결과이다. 하 중-변위 곡선에서 하중이 증가함에 따라 그 하중은 변위 의 $3 / 2$ 에 비례한다는 기존의 접촉역학이론 ${ }^{22}$ 과 잘 일치함 을 알 수 있다.

$$
P=\mathrm{A} \delta^{3 / 2}
$$

위 식에서 $\mathrm{A}$ 는 상수이며, 본 연구에서는 loading 곡선 의 경우, 하중이 변위의 $3 / 2$ 에 비례하여 이론과 비교적 잘 일치한다는 것을 알 수 있다.

Fig. 4는 Hertzian 압흔시험을 주어진 하중에서 행한 후 형성된 손상영역(damage zone)의 직경을 측정한 후 식 (1), (2)에서와 같이 가해준 하중, 초경 구의 반경으로부터 압 흔 응력(indentation stress)과 변형률(indentation strain)을 계산한 후에 그 결과를 그래프로 나타낸 것이다. Fig. 4(a) 는 단층의 bondcoat을 코팅한 위에 단층의 topcoat을 코팅 한 코팅재에 압흔시험한 결과이며, Fig. 4(b)의 경우는 이 층의 bondcoat을 코팅한 위에 다시 이층의 topcoat을 차례

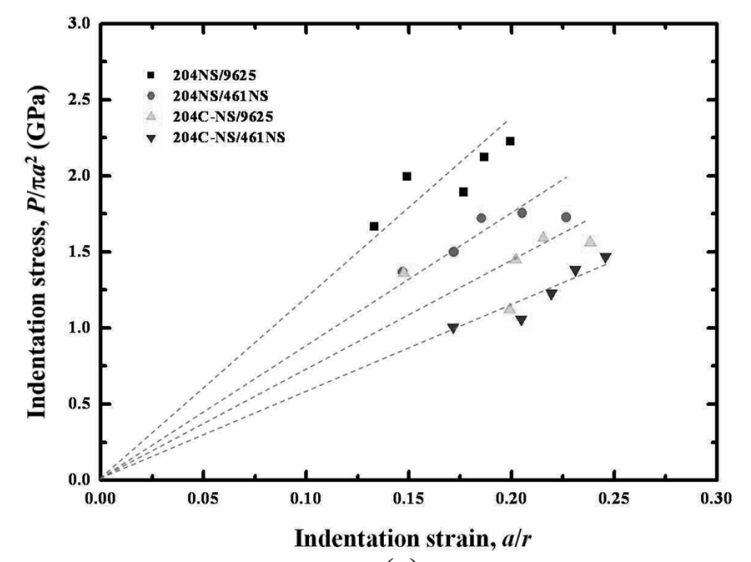

(a)

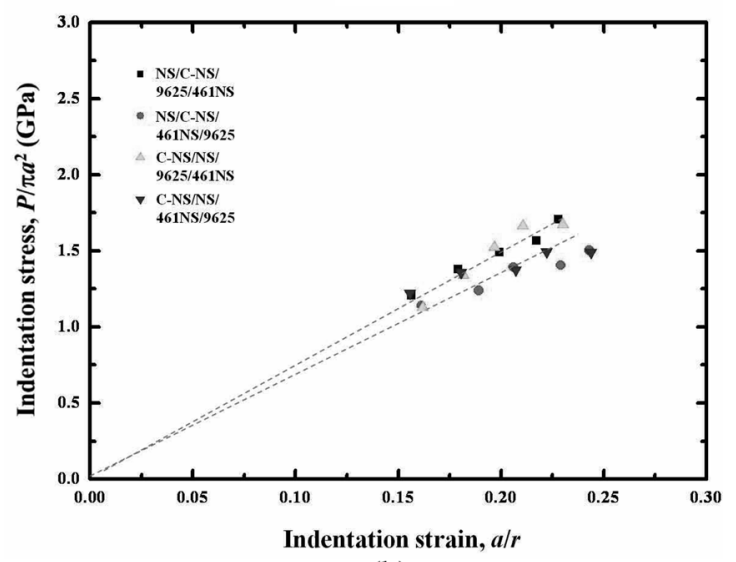

(b)

Fig. 4. Indentation stress-strain curves for (a) single topcoat on the bondcoat and (b) layered double topcoats on the double bondcoats. 


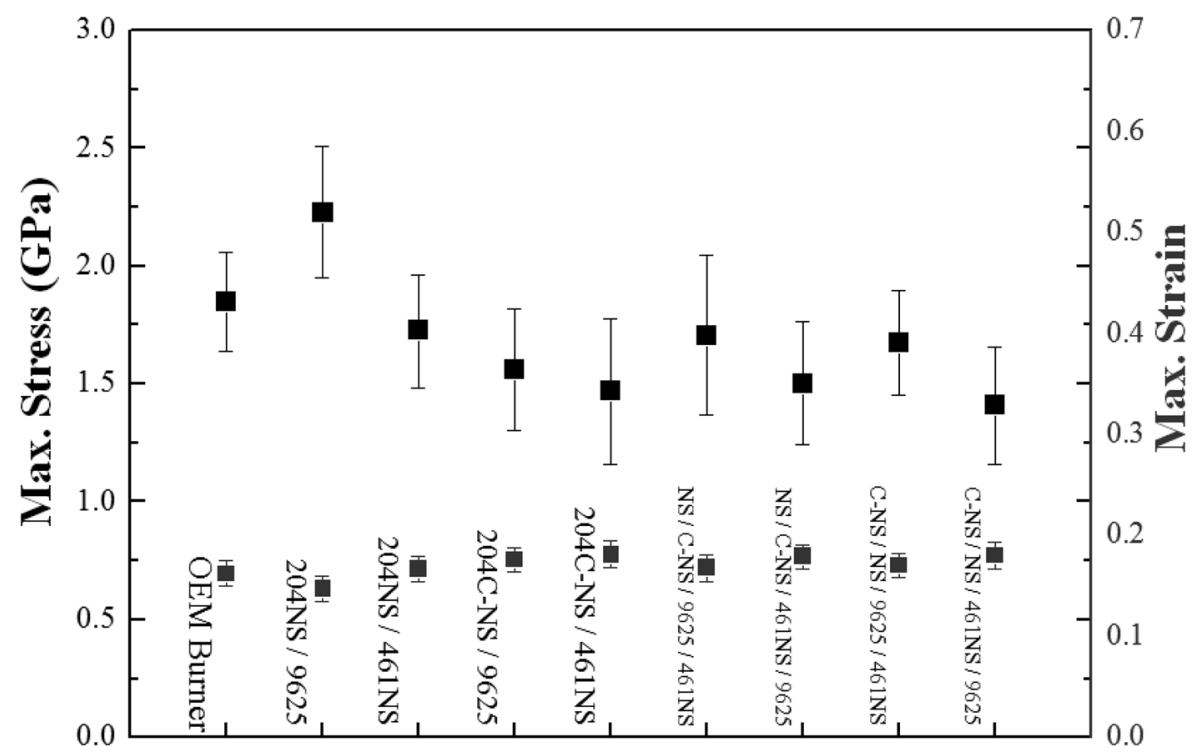

Fig. 5. Plots of the maximum indentation stress and strain at load $P=1500 \mathrm{~N}$ using WC sphere $r=2.32 \mathrm{~mm}$ for each single and double-layered thermal barrier coatings.

로 코팅한 후, topcoat 표면에 압흔시험한 결과이다. 그래 프에서와 같이 압흔 응력-변형율 거동은 초기 분말의 영 향 및 단층/이층의 영향에 크게 의존하였다. Fig. 4(a)의 그래프에서 알 수 있듯이, 461NS보다 9625를 bondcoat으 로 사용한 경우와, 204C-NS 분말보다 $204 \mathrm{NS}$ 분말을 사 용한 경우가 보다 탄성적인 거동을 나타내었다. 이러한 압흔 응력-변형율 곡선간의 차이는 bondcoat과 topcoat을 각각 서로 다른 두 종류의 분말을 사용하여 코팅하였을 경우, Fig. 4(b)와 같이 감소하는 것을 알 수 있다. 일반적 으로 세라믹스의 경우 탄성이 높을수록 기계적 강도, 경 도 등은 우수하나 인성 등은 감소하는 경향이 있다. 반면 소성이 높을수록 인성 등은 우수하나 경도, 강도 등은 감 소하는 것이 일반적이다. 다층상의 코팅재를 제조함으로 써 이러한 서로의 장, 단점을 보완할 수 있을 것으로 생 각된다.

Table 1과 같이 제조된 각각의 열차폐 코팅재의 표면에 Hertzian 압흔시험을 주어진 다양한 하중에서 행한 후 얻은 압흔 응력(indentation stress) - 변형률 (indentation strain)선도 에 대해 일정한 하중 $P=1500 \mathrm{~N}$ 에서의 응력과 변형율을 측 정한 후, 그 최대값에 해당하는 데이터들을 Fig. 5 에 나타 내었다. 동일한 $\mathrm{X}$ 축 상에서 위쪽 데이터는 최대응력을, 아 래쪽 데이터는 최대 변형율을 나타낸다. 최대 변형율은 모 두 유사한 값을 나타낸 반면, 단층의 경우, $204 \mathrm{NS}$ 로 코팅 한 경우가 204C-NS로 코팅한 경우보다 일정한 변형율을 일 으키는데 큰 응력이 필요한 것을 알 수 있다. 이층상으로 코팅한 경우는 topcoat이 204C-NS로 코팅한 경우나, 204NS 로 코팅한 경우에 관계없이 그 최대 응력 값들이 204NS 단 층 코팅재의 최대응력 값과 $204 \mathrm{C}-\mathrm{NS}$ 단층 코팅재의 최대
응력 값 사이의 값을 나타내는 것을 알 수 있다.

각 열차폐 코팅재의 표면에 Hertzian 압흔시험을 최대 하중 $P=1500 \mathrm{~N}$ 까지 행할 때 변위센서에 의해 얻은 Fig. 3(b)과 같은 하중-변위 곡선을 모두 얻은 후, 그 중 최대 변위량을 Fig. 6에 도시하여 나타내었다. 그 결과 204NS 로 단층의 열차폐재를 코팅한 경우의 변형율은 $204 \mathrm{C}-\mathrm{NS}$ 로 코팅한 경우보다 상대적으로 작은 것을 알 수 있으며, 이층상으로 코팅한 경우의 변형율 값들은 $204 \mathrm{NS}$ 단층으 로 코팅한 코팅재의 변형율 보다는 크고, 204C-NS로 단 층으로 코팅한 코팅재의 변형율보다는 작은 값들을 각각 나타내었다.

한편 각 열차폐 코팅재의 표면에 Vickers 압흔시험을 최 대 하중 $P=10 \mathrm{~N}$ 까지 행한 후 경도 값을 측정하여 Fig. 7에 막대그래프를 사용하여 도시하였다. 단층상의 경우, $204 \mathrm{NS}$ 로 코팅한 경우의 경도 값이 상대적으로 우수한 것을 알 수 있으며, 이층상으로 코팅한 경우가, 단층으로 코팅한 경우보다 우수한 경도 값을 나타내었다. 이는 이층상으로 제작할 경우, 서로 다른 하부의 단층상들의 영향을 받으 며, 잔류압축응력의 영향으로 보다 우수한 경도 값을 나 타낸 것으로 생각된다.

\section{4. 결 론}

본 연구에서는 서로 다른 종류의 상용분말들을 사용하 여 단층 및 이층상의 bondcoat과 topcoat층을 형성시킨 후, Vickers 압입시험으로 경도를 평가하고, Hertzian 압입시험 에 의해 압흔응력-변형율, 하중-변위 곡선 등을 얻어 그 거 동을 분석, 비교하였다. Bondcoat 분말로서는 입자의 형상 


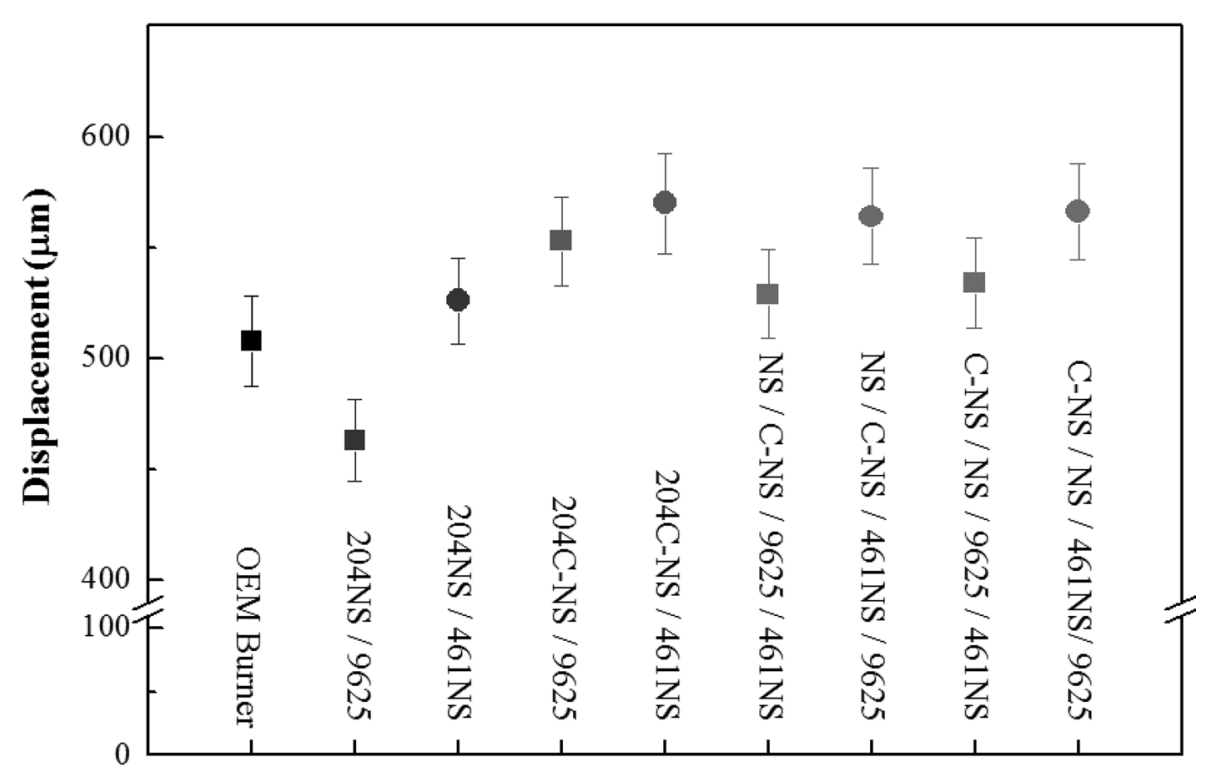

Fig. 6. Plots of the maximum displacement at load $P=1500 \mathrm{~N}$ using WC sphere $r=2.32 \mathrm{~mm}$ for each single and double- layered thermal barrier coatings.

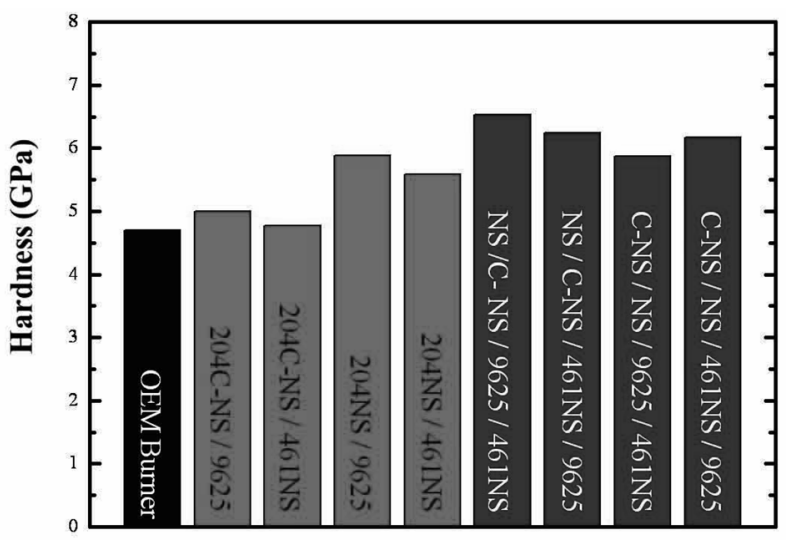

Fig. 7. Hardness measured by Vickers indentation on the surface of single and double- layered thermal barrier coating.

이 각진 AMDRY $461 \mathrm{NS}$, 입자의 형상이 구형인 AMDRY 9625 를 사용하여 코팅하였고, Topcoat 분말로서는 입자분 포가 넓은 $204 \mathrm{NS}$, 입자분포가 상대적으로 좁은 $204 \mathrm{C}-$ $\mathrm{NS}$ 분말을 사용하여 코팅하였다. 기계적 거동을 평가하 기 위해 초경 구형압자를 이용하여 일정한 속도로 복합 재 시험편의 표면을 일정한 하중까지 압흔(indentation)하 였다가 동일한 속도로 하중을 제거하였고, 이 때 변위센 서를 이용하여 하중-변위 곡선을 얻어내었다. 압흔 후에 표면에 형성된 손상(damage)을 광학현미경으로 관찰하여, 다양한 하중 하에서의 손상크기로 부터 압흔응력, 압흔 변형율을 계산하여 그래프로 도시하였다.

그 결과 bondcoat 분말의 경우 AMDRY 9625를 코팅한
경우가 $461 \mathrm{NS}$ 를 이용해 코팅한 경우보다 탄성적인 거동 을 나타내었으며, topcoat 분말의 경우 $204 \mathrm{NS}$ 를 코팅한 경우가 $204 \mathrm{C}-\mathrm{NS}$ 분말을 이용하여 코팅한 경우보다 기공 율이 작아 보다 탄성적인 거동을 나타내었다. 또한 AMDRY 9625와 $204 \mathrm{NS}$ 분말을 이용하여 코팅한 열차폐 코팅재의 경우가 일정한 변형율을 일으키는데 상대적으로 큰 응력 이 필요하였고, 일정한 하중 하에서 작은 변형율과 변형 량을 나타내었다.

두 종류의 $\mathrm{TBC}$ 상용분말을 사용하여 이층으로 코팅한 후 압흔응력-변형율, 하중-변위 곡선을 분석한 결과, 단층 으로 코팅한 두 경우의 각각의 해당 값들의 범위 내에서 서로 다른 값들을 나타내었다. 따라서 다양한 용도 하에 서 손상저항성이 우수한 열차폐 코팅재의 제작이 초기 분 말 및 다층상의 제어로서 가능하다는 결론을 본 연구결 과를 통해 제시할 수 있었다.

\section{Acknowledgment}

본 논문은 지식경제부 에너지기술개발사업(2009T100200025) 과 2011년도 국민대학교 교내연구비의 지원금으로 수행된 연구결과이며, 실험장비와 코팅실험에 도움을 주신 한양대 학교 백운규 교수님, 창원대학교 정연길 교수님께 감사드 립니다.

\section{REFERENCES}

1. N. P. Bansal and D. Zhu, "Effects of Doping on Thermal Conductivity of Pyrochlore Oxides for Advanced Thermal Barrier Coatings," Mater. Sci. Eng. A., 459 192-95 (2007). 2. K. S. Lee, K. I. Jung, Y. S. Heo, T. W. Kim, Y. G. Jung, and U. 
Paik, "Thermal and Mechanical Properties of Sintered Bodies and EB-PVD Layers of $\mathrm{Y}_{2} \mathrm{O}_{3}$ Added $\mathrm{Gd}_{2} \mathrm{Zr}_{2} \mathrm{O}_{7}$ Ceramics for Thermal Barrier Coatings," J. Alloy Compd., 507 448-55 (2010).

3. S. I. Jung, J. H. Kim, J. H. Lee, Y. G. Jung, U. Paik, and K. S. Lee, "Microstructure and Mechanical Properties of Zirconia-based Thermal Barrier Coatings with Starting Powder Morphology," Surf. Coat. Tech., 204 [1] 802-6 (2009).

4. R. M. Leckie, S. Kramer, M. Ruhle, and C. G. Levi, "Thermochemical Compatibility between Alumina and $\mathrm{ZrO}_{2}-\mathrm{GdO}_{3 / 2}$ Thermal Barrier Coatings," Acta Mater., 53 3281-92 (2005).

5. S. Y. Yoon, S. M. Lee, K. B. Shim, and H. T. Kim, "High Temperature Thermal Conductivities in $\mathrm{La}_{2} \mathrm{Ce}_{2} \mathrm{O}_{7}-\mathrm{Gd}_{2} \mathrm{Ce}_{2} \mathrm{O}_{7}-\mathrm{Y}_{2} \mathrm{Ce}_{2} \mathrm{O}_{7}$ Pyrochlore System for Thermal Barrier Coatings," J. Kor Ceram. Soc., 44 [7] 387-92 (2007).

6. K. I. Jung, T. W. Kim, U. Paik, and K. S. Lee, "Mechanical Properties of Zirconia-Based Ceramic Materials for Thermal Barrier Coating," J. Kor. Ceram. Soc., 43 [8] 498-503 (2006).

7. K. H. Kwak, B. C. Shim, S. M. Lee, Y. S. Oh, H. T. Kim, B. K. Jang, and S. W. Kim, "Formation and Thermal Properties of Flurite-Pyrochlore Composite Structure in $\mathrm{La}_{2}\left(\mathrm{Zr}_{\mathrm{x}} \mathrm{Ce}_{1-\mathrm{x}}\right)_{2} \mathrm{O}_{7}$ Oxide System," Mater. Lett., 65 [19-20] 2937-40 (2011).

8. A. G. Evans and J. W. Hutchinson, "The Mechanics of Coating Delamination in Thermal Gradients," Surf. Coat. Tech., 201 7905-16 (2007).

9. C. Mercer, S. Faulhaber, A. G. Evans, and R. Darolia, "A Delamination Mechanism for Thermal Barrier Coatings Subject to Calcium-Magnesium-Alumino-Silicate (CMAS) Infilration," Acta Mater, 53 1029-39 (2005).

10. S. H. Park, S. K. Kim, T. W. Kim, U. Paik, and K. S. Lee, "Indentation on YSZ Thermal Barrier Coating Layers Deposited by Electron Beam PVD," Phil. Mag., 86 [33-35] 5453-63 (2006).

11. J. C. Jang and S. C. Choi, "Numerical Simulation for Residual Stress Distributions of Thermal Barrier Coatings by High Temperature Creep in Thermally Grown Oxide," J. Kor. Ceram. Soc., 43 [8] 479-85 (2006).

12. A. M. Limarga, T. L. Duong, G. Gregori, and D. R. Clarke,
"High-Temperature Vibration Damping of Thermal Barrier Coating Materials," Surf. Coat. Tech., 202 [4-7] 693-97 (2007).

13. M. Gell, L. Xie, X. Ma, E. H. Jordan, and N. P. Padture, "Highly Durable Thermal Barrier Coatings Made By the Solution Precursor Plasma Spray Process," Surf. Coat. Tech., 177-178 97-102 (2004).

14. A. D. Jadhav and N. P. Padture, "Mechanical Properties of Solution-Precursor Plasma-Sprayed Thermal Barrier Coatings," Surf. Coat. Tech., 202 4976-79 (2008).

15. A. Vaidya, V. Srinivasan, T. Streibl, M. Friis, W. Chi, and S. Sampath, "Process Maps for Plasma Spraying of Yttria-Stabilized Zirconia: An Integrated Approach to Design, Optimization and Reliability," Mater. Sci. Eng. A., 497 239-53 (2008).

16. S. Y. Chun, "Microstructure and Mechanical Properties of Nanocrystalline TiN Films Through Increasing Substrate Bias," J. Kor. Ceram. Soc., 47 [6] 479-84 (2010).

17. D. Lee, T. W. Kim, and K. S. Lee, "Design of Thermal Barrier Coatings using Gadolinium Zirconate Ceramics : A Study on Gadolinium Zirconate/YSZ Bilayers," J. Ceram. Soc. Japan, 117 [5] 550-54 (2009).

18. Z. Xu, L. He, R. Mu, X. Zhong, Y. Zhang, J. Zhang, and X. Cao, "Double-Ceramic-Layer Thermal Barrier Coatings of $\mathrm{La}_{2} \mathrm{Zr}_{2} \mathrm{O}_{7}$ ' YSZ Deposited by Electron Beam-Physical Vapor Deposition," J. Alloy Compd., 478 168-72 (2009).

19. B. R. Lawn, "Indentation of Ceramics with Spheres : A Century after Hertz," J. Am. Ceram. Soc., 81 [8] 1977-94 (1998).

20. S. W. Myoung, J. H. Kim, W. R. Lee, Y. G. Jung, K. S. Lee, and U. Paik, "Microstructure Design and Mechanical Properties of Thermal Barrier Coatings with Layered Top and Bond Coats," Surf. Coat. Tech., 205 1229-35 (2010).

21. X. Z. Hu and B. R. Lawn, "A Simple Indentation Stress-Strain Relation for Contacts with Spheres on Bilayer Structures," Thin Solid Films, 322 224-32 (1998).

22. W. C. Oliver and G. M. Pharr, "An Improved Technique for Determining Hardness and Elastic Modulus using Load and Displacement Sensing Indentation Experiments," J. Mater. Res., 7 1564-83 (1992). 